\title{
Characterization of $\mathrm{Zn}$ (II)-responsive ribosomal proteins YkgM and L31 in E. coli
}

\author{
M. Patrick Hensley, Thusitha S. Gunasekera, J. Allen Easton, Tara K. Sigdel, Stacy A. \\ Sugarbaker, Lindsey Klingbeil, Robert M. Breece, David L. Tierney, and Michael W. \\ Crowder $^{*}$ \\ Department of Chemistry and Biochemistry, 160 Hughes Hall, Miami University, Oxford, $\mathrm{OH}$ \\ 45056
}

\begin{abstract}
RT-PCR and DNA microarrays were used to probe for Zn(II)-responsive genes in E. coli cells that were made $\mathrm{Zn}$ (II) deficient. Microarray data revealed 114 genes were significantly up-regulated and 146 genes were significantly down-regulated in $\mathrm{Zn}$ (II) deficient conditions. The three most up-regulated genes were (1) $z n u A$, which encodes for a periplasmic protein known to be involved with $\mathrm{Zn}(\mathrm{II})$ import, (2) yod $A$, which encodes for a periplasmic protein with unknown function, and (3) $y \mathrm{kgM}$, which encodes for a ribosomal protein that is thought to be a paralog of ribosomal protein L31. YodA was over-expressed and purified as a maltose binding protein (MBP) fusion protein and shown to tightly bind 4 equivalents of $\mathrm{Zn}(\mathrm{II})$. Metal analyses showed that MBP-YkgM does not bind $\mathrm{Zn}(\mathrm{II})$. On the other hand, MBP-L31 tightly binds 1 equivalent of $\mathrm{Zn}$ (II). EXAFS studies on MBP-L31 suggest a ligand field of 1 histidine, 1 cysteine, and 2 additional N/O scatterers. Site-directed mutagenesis studies suggest that Cys 16 coordinates $\mathrm{Zn}$ (II) in MBP-L31 and that the other three cysteines do not bind metal. These results are discussed in light of $\mathrm{Zn}$ (II) starvation model that has been postulated for $B$. subtilis.
\end{abstract}

\section{Keywords}

ribosomal protein L31; EXAFS; Zn(II) homeostasis; DNA microarrays

\section{Introduction}

Zinc is an essential transition metal required for life in all organisms [1]. It plays a key catalytic or structural role in members from all six major classes of enzymes [2-4]. Despite how critical its presence inside cells appears to be, little is understood about the intracellular homeostasis of this metal. Currently, there are two known import systems and three known export systems for $\mathrm{Zn}(\mathrm{II})$ in prokaryotic cells. ZntA, ZitB, and YiiP are efflux pumps that remove $\mathrm{Zn}(\mathrm{II})$ from the cytoplasm of $E$. coli cells [5, 6]. The transcription of $z n t A$ is regulated by ZntR, a MerR homolog that up-regulates transcription as a result of $\mathrm{Zn}$ (II) binding $[7,8]$. ZitB and YiiP are members of the cation diffusion facilitator family that is reported to be regulated by $\mathrm{Zn}(\mathrm{II})[6,9]$. The ZnuABC and ZupT systems are used to control

\footnotetext{
(C) 2011 Elsevier Inc. All rights reserved.

*Corresponding author: Michael W. Crowder, Phone: (513) 529-7274, Fax: (513) 529-5715, crowdemw@ muohio.edu.

Publisher's Disclaimer: This is a PDF file of an unedited manuscript that has been accepted for publication. As a service to our customers we are providing this early version of the manuscript. The manuscript will undergo copyediting, typesetting, and review of the resulting proof before it is published in its final citable form. Please note that during the production process errors may be discovered which could affect the content, and all legal disclaimers that apply to the journal pertain.
} 
influx of $\mathrm{Zn}(\mathrm{II})$ into the cytoplasm of $E$. coli cells [10]. The $z n u A$ operon is transcriptionally-controlled by Zur, a Zn(II)-sensitive Fur homolog [10]. ZupT is a member of the ZIP family of proteins [11]. There is also some evidence that PitA, a phosphate transporter, is zinc responsive and may be involved in zinc transport [12].

In an effort to better understand zinc trafficking, several groups have reported proteomic and cDNA microarray experiments to study the effects of zinc excess and zinc deficiency on $E$. coli $[13,14,15,16-18]$ and to identify $\mathrm{Zn}(\mathrm{II})$-responsive proteins/genes. The rationale for most of these studies is that the expression levels of genes/proteins involved in $\mathrm{Zn}$ (II) homeostasis would be affected by cytoplasmic Zn(II) levels. When comparing previous genomic/proteomic experiments however, major differences in growth media and stress times are evident. Poole and coworkers used glycerophosphate-containing minimal medium $[14,15]$, while Yamamoto et al. and Brocklehurst et al. used Luria-Bertani medium [13, 16] to study $\mathrm{Zn}$ (II)-excess conditions. Sigdel et al. used a chemically-defined minimal medium to study $\mathrm{Zn}$ (II)-deficient conditions [17]. Stress times varied from 5 minutes by Yamamoto et al. [16] to overnight batch cultures by Brocklehurst et al. [13], with 5 hours by Sigdel et al. [17]. All of these differences have resulted in many differentially-expressed genes being reported, and there is little or no overlap of genes found in the studies. It has recently been shown that the proteomic profile of $\mathrm{Zn}$ (II)-stressed E. coli cells changes over time [18]. It is unquestionable that gene expression is also time-dependent and that some genes possibly involved in $\mathrm{Zn}$ (II) homeostasis were missed due to the incorrect choice of time to harvest the cells after stress for microarray studies.

In B. subtilis ribosomal protein $\mathrm{L} 31$ and its homolog protein YtiA have recently been hypothesized to participate in a $\mathrm{Zn}$ (II) starvation model [19]. Under Zn(II) limiting conditions, the $\mathrm{Zn}$ (II)-binding ribosomal protein $\mathrm{L} 31$ (called $\mathrm{C}+$ because it is thought to bind $\mathrm{Zn}$ (II) with at least two cysteine residues) is replaced with the non $\mathrm{Zn}$ (II)-binding paralog YtiA (called C- that lacks the CXXC motif found in L31) [19, 20]. The replacement of $\mathrm{Zn}$ (II)-binding L31 with YtiA, which does not bind Zn(II), is thought to mobilize ribosomeassociated $\mathrm{Zn}$ (II) by releasing $\mathrm{Zn}$ (II)-binding ribosomal proteins into the cell that are then degraded and thereby releasing $\mathrm{Zn}$ (II). In this model a significant amount of $\mathrm{Zn}$ (II) is released into the cell, and ribosome function is maintained. This $\mathrm{Zn}(\mathrm{II})$ starvation model suggests that the ribosome may serve as a possible active participant in intracellular $\mathrm{Zn}$ (II) homeostasis.

This study was conducted to determine the optimal time for $\mathrm{Zn}$ (II)-induced transcription in an effort to identify $\mathrm{Zn}$ (II)-responsive genes and if evidence could be found for this $\mathrm{Zn}$ (II) starvation model in E. coli. Using quantitative, real-time polymerase chain reaction (qPCR), the time-dependent expression levels of most genes predicted to be involved with $\mathrm{Zn}$ (II) homeostasis were monitored. It is shown here that several Zur-regulated genes ( $Z n u A$, $y \mathrm{kgM}, \operatorname{yodA}$ ) were up-regulated as much as 1000 -fold over control after 30 minutes of stress, while the levels of other, non zur-regulated genes (zupT, zntA, zitB) as well as $16 \mathrm{~S}$ RNA did not change. The optimum time of stress was used to refine and enhance the subsequent cDNA array studies [17], which revealed 114 genes up-regulated and 146 downregulated. All of the Zur-regulated proteins, with genes on the microarray chips, were overexpressed, purified, and analyzed for $\mathrm{Zn}$ (II) binding. The $y \mathrm{kgM}$ gene, which displayed the largest up-regulation, encodes a hypothetical protein that is a homolog of the $\mathrm{Zn}$ (II)-binding, ribosomal protein L31 [21]. YkgM and L31 were cloned, over-expressed, purified, and subjected to elemental analyses. The data show that L31 binds 1.2 equivalents of $\mathrm{Zn}$ (II) and that YkgM binds no Zn(II). Spectroscopic and mutagenesis studies on L31 suggest that the $\mathrm{Zn}$ (II) binding motif of L31 contains one cysteine at position 16 in the amino acid sequence, one histidine residue, and two nitrogen or oxygen ligands. Nonetheless, an examination of 
L31 when bound to the ribosome cast doubts that L31 serves as a C+ member. By using previous crystal structures, an alternative $\mathrm{C}+/ \mathrm{C}-$ paralogous pair is identified.

\section{Experimental procedures}

\subsection{Cultures for $q R T-P C R$ studies and DNA microarrays}

Nine 1-liter flasks of minimal medium [22] were inoculated with E. coli BW25113 (obtained National BioResource Project, National Institute of Genomics, Japan) cells from an overnight preculture and grown to an $\mathrm{OD}_{600}$ of $0.55-0.60$, at which time 3 flasks were made $10 \mu \mathrm{M}$ in TPEN and 3 flasks were left as controls. Samples $(5 \mathrm{~mL})$ were extracted from each flask at $0,0.5,1,5,30,60,120$, and 240 minutes after adding TPEN, immediately frozen in liquid nitrogen, and stored at $-80^{\circ} \mathrm{C}$. For cDNA array studies, E. coli BW25113 cells were grown at $37^{\circ} \mathrm{C}$ with continuous agitation at $200 \mathrm{RPM}$ in a defined medium described previously [17]. This medium contained $10 \mathrm{mM}$ glycerol as the sole carbon source. The glycerol was added to a solution containing $40 \mathrm{mM}$ MES (morpholineethanesulfonic acid), $19 \mathrm{mM} \mathrm{NH}_{4} \mathrm{Cl}, 13 \mathrm{mM} \mathrm{KCl}, 5.0 \mathrm{mM} \mathrm{K}_{2} \mathrm{SO}_{4}, 68 \mu \mathrm{M}$ $\mathrm{CaCl}_{2}$, and trace elements $\left(19 \mu \mathrm{M} \mathrm{FeCl}_{3} \cdot 6 \mathrm{H}_{2} \mathrm{O}, 600 \mathrm{nM} \mathrm{ZnO}, 400 \mathrm{nM} \mathrm{CuCl}{ }_{2} \cdot 2 \mathrm{H}_{2} \mathrm{O}, 344 \mathrm{nM}\right.$ $\mathrm{Co}\left(\mathrm{NO}_{3}\right)_{2} \cdot 6 \mathrm{H}_{2} \mathrm{O}, 16 \mu \mathrm{M} \mathrm{H}_{3} \mathrm{BO}_{3}$ in distilled water). After the $\mathrm{pH}$ was adjusted to 7.4 and the solution was autoclaved, the solution was made $1 \mathrm{mM}$ in $\mathrm{MgCl}_{2}$ and $7.6 \mathrm{mM}$ in $\beta$ glycerophosphate (as a phosphate source). Cultures were grown to mid log phase $\left(\mathrm{OD}_{600}=\right.$ 0.5 ), and cells were treated with $10 \mu \mathrm{M}$ TPEN. Cells were shaken at $37^{\circ} \mathrm{C}$ for $30 \mathrm{~min}$ and harvested for total RNA extraction. $\mathrm{OD}_{600}$ values for TPEN-treated and control cultures were 0.56 and 0.58 , respectively.

\section{2. qRT-PCR studies}

A RNeasy mini kit (Qiagen) was used to isolate RNA following the manufacturer's instructions. Further purification was accomplished using the RNeasy MinElute Cleanup Kit (Qiagen). The samples were then subjected to genomic DNA digestion using RNase-free DNase (Ambion). Purified and DNA-free RNA was then quantitated using a NanoDrop UVVIS spectrophotometer. All primers except for 16S RNA were designed using PrimerQuest software from the Integrated DNA Technologies (IDT) website (http://www.idtdna.com). Primers obtained from IDT were: 16S RNA 5': 5'ATTGACGTTACCCGCAGAAGA 3'; 16S RNA 3': 5'GGGATTTCACATCCGACTTGA 3'; yodA 5': 5'GGCTGTTGCTTTAGGTGTCT 3'; YodA 3': 5'TTTGCCGTGTGAGTGATG 3'; ykgM 5': 5'GTCTCTTCTAAATCGCACCC 3'; ykgM 3': 5'TCCTTCTGATGCCACTGTTC 3'; znuA 5': 5'ATTACCAGGAGCGAAGCA 3'; znuA3': 5'TCATCAGTAGCGGTTTCACA 3'; zntA5': 5'CACAGGTTGCTGAACTCGCC 3'; zntA3': 5'TCAATGCCAGACCCGACCA 3'; zupT5': 5'GCTGAAGGAATGTCGCCT 3'; zupT3': 5'ATAGCCAAGCAGACCGAA 3'; zitB5': 5'CGCACTCACACTCACACAC 3'; zitB3': 5'CATACAACAAGCGACGAGCA 3'. One-step, real-time PCR was accomplished using the iScript One-Step RT-PCR Kit with SYBR Green (Bio-Rad). Reactions included $12.5 \mu \mathrm{L}$ SYBR Green reaction mix, $1 \mu \mathrm{L}$ reverse transcriptase, $100 \mathrm{ng}$ RNA, $50-150 \mathrm{nM}$ primers, and $\mathrm{H}_{2} \mathrm{O}$ up to a $25 \mu \mathrm{L}$ total reaction volume. Reactions were run using a RotorGene 3000 thermocycler. Standard curves were run for each gene, using 0.5-200 ng RNA, and each reaction was conducted in triplicate. A standard curve was then prepared by plotting the cycle threshold (Ct) vs. log ng RNA. All experiments were conducted with (-)RT controls, and values for RNA amounts were then determined using the standard curve. Fold changes were determined by comparing the TPEN-stressed samples to control samples. Standard deviations for each data point were obtained from the actual RNA amounts determined by the standard curve method for each sample. 


\section{3. cDNA microarrays}

Total RNA was extracted using the Qiagen RNeasy Mini kit according to the manufacturer's protocol. The isolated RNA was then subjected to RT-PCR using the $z n u A$ gene to ensure that the znuA gene had been up-regulated as in previous experiments. This control was important to ensure that the growth medium did not affect expression levels of the genes. cDNA synthesis, fragmentation and labeling, and washing and scanning of E. coli GeneChip arrays were performed according to the instructions of the manufacturer (Affymetrix Technical Manual, Affymetrix, Inc., USA). Biotin-labeled fragmented cDNA $(2.0 \mu \mathrm{g})$ was hybridized to $E$. coli antisense genome arrays (Affymetrix) at $45^{\circ} \mathrm{C}$ for $16 \mathrm{~h}$ as recommended in the GeneChip technical manual (Affymetrix). The data were collected by using Affymetrix GeneChip Scanner 3300. Array hybridizations were carried out for three RNA samples prepared from three independent cultures. Intra-chip normalizations were performed, and manipulation and filtering of the data were conducted as previously described [23]. Background-subtracted data sets were used to calculate up-regulated and down-regulated genes based on fold changes of greater than 2 .

\subsection{Cloning, over-expression, and purification of YodA, YkgM, and L31}

Two different primer sets were designed to amplify from $E$. coli genomic DNA the coding region of YodA and to introduce NdeI and HindIII restriction sites flanking the gene. The first primer set replaced the native leucine-encoding start codon with a methionine-encoding codon: MBPYodAstart: 5'-CATATGGCGATTCGTCTTA-3' and MBPYodAterm: 5'AAGCTTCAATGAGACATCATTTCCTC-3'. The second primer set left the native leucine-encoding start codon YodAFWDMBP: 5'-CATATCTTGGCGATTCGTCTTA-3'. The $y \mathrm{kgM}$ gene was amplified from genomic E. coli DNA from the BL21(DE3) strain using the forward primer 5'-AAA AAA ACA TAT GAA AAT GTA CGT GGT ATC -3' and reverse primer 5'-AAA AAG CTT ATG CCC TGC CCT CGC AG -3', respectively, and these primers introduced $\mathrm{NdeI}$ and $H$ indIII restriction sites flanking the $y \mathrm{kgM}$ gene. The $L 31$ gene was cloned from genomic E. coli DNA from the BL21(DE3) strain using the following forward and reverse primers, 5' - AAA AAA ACA TAT GAA AAA AGA TAT TCA CCC G -3' and 5' - AAA AAG CTT TTA TTT GCT GCC CGG GAT GT -3', respectively, and these primers introduced HindIII and NdeI restriction sites flanking the L31 gene. The resulting PCR products were digested with $N d e I$ and HindII and ligated into digested pIAD14 [24] to generate pIAD14-YodA, pIAD14-L31 and pIAD14-YkgM, respectively. The genes were verified with DNA sequencing.

The over-expression plasmids for YodA, YkgM, and L31 were transformed into BL21(DE3) E. coli cells. In the case of YodA, the over-expression plasmid was also transformed into BL21-CodonPlus $^{\mathrm{R}}$ (DE3)-RIPL and Rosetta ${ }^{\mathrm{TM}}$ 2(DE3) cells. These cells were grown in LB medium supplemented with $25 \mu \mathrm{g} / \mathrm{mL}$ of kanamycin at $37^{\circ} \mathrm{C}$ to an $\mathrm{OD}_{600 \mathrm{~nm}}$ of $0.8-1.0$, and protein production was induced by making the cultures $0.20 \mathrm{mM}$ in isopropyl- $\beta-D$ thiogalactopyranoside (IPTG). The cultures were shaken for three hours at $37^{\circ} \mathrm{C}$. The cells were harvested by centrifugation for ten minutes at $6831 \times \mathrm{g}$. The cell pellets were resuspended with $20 \mathrm{~mL}$ of ice-cold, $20 \mathrm{mM}$ Tris-Cl, $\mathrm{pH} 7.6$, containing $200 \mathrm{mM} \mathrm{NaCl}$. The cells were ruptured by three passes through a French pressure cell at 16,000 psi. The cell extracts were centrifuged at $23,419 \times \mathrm{g}$ for twenty five minutes

The supernatants were loaded at $4{ }^{\circ} \mathrm{C}$ onto Amylose columns $(16 \times 20 \mathrm{~mm})$, which were preequilibrated with $20 \mathrm{mM}$ Tris-Cl, pH 7.6, containing $200 \mathrm{mM} \mathrm{NaCl}$. Bound proteins were eluted from the columns using $20 \mathrm{mM}$ Tris-Cl, $\mathrm{pH} 7.6$, containing $200 \mathrm{mM} \mathrm{NaCl}$ and 10 $\mathrm{mM}$ maltose. The fractions containing protein of the correct molecular weight were collected and concentrated using an Amicon ultrafiltration unit equipped with a YM-10 nitrocellulose membrane. The concentrated proteins were flash-frozen in liquid nitrogen and 
stored at $-80{ }^{\circ} \mathrm{C}$ until further use. The purified proteins were quantitated using their absorbances at $280 \mathrm{~nm}$. The molar extinction coefficients of $99,710 \mathrm{M}^{-1} \mathrm{~cm}^{-1}$ for MBPYodA, $71,120 \mathrm{M}^{-1} \mathrm{~cm}^{-1}$ for MBP-YkgM, and $64,720 \mathrm{M}^{-} 1 \mathrm{~cm}^{-1}$ for MBP-L31 were calculated from the amino acid compositions using the protein calculator (http://www.scripps.edu/ edputnam/protcalc.html).

\subsection{Metal analyses}

Purified proteins were diluted to $20 \mu \mathrm{M}$ with deionized water and analyzed for metal, as described below (called as-isolated samples). To create $\mathrm{Zn}$ (II)-loaded samples, $1 \mathrm{~mL}$ of 300 $\mu \mathrm{M}$ purified protein was incubated with ten equivalents of $\mathrm{Zn}$ (II) for thirty minutes at $4{ }^{\circ} \mathrm{C}$, and the resulting mixture was dialyzed against $2 \times 2 \mathrm{~L}$ of $20 \mathrm{mM}$ Tris-Cl, $\mathrm{pH} 7.6$, for eight hours each. The $\mathrm{Zn}$ (II)-loaded samples were diluted to $20 \mu \mathrm{M}$ with deionized water. The metal content of the samples was determined using a Thermo Jarrell Ash ICP-AES spectrometer, using an emission wavelength of $213.856 \mathrm{~nm}$. Metal analyses were conducted in triplicate. Calibration curves were generated with the use of at least four standards, with correlation coefficients of greater than 0.999 , and these calibration curves were used to determine the $\mathrm{Fe}(\mathrm{II}), \mathrm{Ni}(\mathrm{II}), \mathrm{Mn}(\mathrm{II})$, and $\mathrm{Zn}$ (II) content in the samples.

\subsection{Site-directed mutagenesis studies}

The site-directed mutagenesis of L31 was conducted using the Stratagene QuikChange sitedirected mutagenesis kit, according to manufacturer's instructions. The cysteine residue present at amino acid position 16 was changed to a serine residue to produce the C16S pIAD14-L31 plasmid using the following forward and reverse mutant primers, respectively: 5'- AAA TAC GAA GAA ATT ACT GCT AGC TCG TCT TGC GGT AAC GTA ATG -'3 and 5'- CAT TAC GTT ACC GCA AGA CGA GCT AGC AGT AAT TTC TTC GTA TTT -'3. The cysteine residue present at amino acid position 18 was changed to a serine residue to produce the C18S pIAD14-L31 plasmid using the following forward and reverse mutant primers, respectively: 5'- GAA ATT ACT GCT AGC TGC TCT TCG GGT AAC GTA ATG AAA ATC CGC -'3 and 5'- GCG GAT TTT CAT TAC GTT ACC CGA AGA GCA GCT AGC AGT AAT TTC -'3. The cysteine residues present at amino acid positions 37 and 40 were changed to serine residues to produce the C37/40S pIAD14-L31 plasmid using the following forward and reverse mutant primers, respectively: 5'- CTG AAC CTC GAC GTG TCG AGC AAG TCG CAC CCG TTC TTC ACT GGC -'3 and 5'- GCC AGT GAA GAA CGG GTG CGA CTT GCT CGA CAC GTC GAG GTT CAG -'3. The C16S, C18S, and C37/40S pIAD14-L31 plasmids were transformed into E. coli BL21(DE3) cells as described above. The mutants were verified by DNA sequencing.

\subsection{EXAFS studies}

Samples of Zn(II)-supplemented L31 ( 800-900 $\mu$ M, including 20\% (v/v) glycerol added as a glassing agent) were loaded in Lucite cuvettes with $6 \mu \mathrm{m}$ polypropylene windows and frozen rapidly in liquid nitrogen. X-ray absorption spectra were measured at the National Synchrotron Light Source (NSLS), beamline X3B, with a Si(111) double crystal monochromator; harmonic rejection was accomplished using a Ni focusing mirror. Fluorescence excitation spectra for all samples were measured with a 13-element solid-state Ge detector array. Samples were held at $\sim 15 \mathrm{~K}$ in a Displex cryostat during XAS measurements. X-ray energies were calibrated by reference to the absorption spectrum of the cobalt metal foil, measured concurrently with the protein spectra. All of the data shown represent the average of $\sim 12$ total scans, from two independently prepared samples each. Data collection and reduction were performed according to published procedures [25] with $E_{0}$ set to $9675 \mathrm{eV}$. The Fourier-filtered EXAFS were fit to Equation 1 using the nonlinear least-squares engine of IFEFFIT that is distributed with SixPack. Sixpack is available free of charge from its author, Sam Webb, at 
http://www-ssrl.slac.stanford.edu/ swebb/sixpack.htm. IFEFFIT is open source software available from http://cars9.uchicago.edu/ifeffit.

$$
\chi(k)=\sum \frac{N_{a s} A_{s}(k) S_{c}}{k R_{a s}^{2}} \exp \left(-2 k^{2} \sigma_{a s}^{2}\right) \exp \left(-2 R_{a s} / \lambda\right) \sin \left[2 k R_{a s}+\varphi_{a s}(k)\right]
$$

In Eq. $1, N_{a s}$ is the number of scatterers within a given radius $\left(R_{a s}, \pm \sigma_{a s}\right), A_{s}(k)$ is the backscattering amplitude of the absorber-scatterer (as) pair, $S_{c}$ is a scale factor, $\varphi_{a s}(k)$ is the phase shift experienced by the photoelectron, $\lambda$ is the photoelectron mean free-path, and the sum is taken over all shells of scattering atoms included in the fit. Theoretical amplitude and phase functions, $A_{s}(k) \exp \left(-2 R_{a s} / \lambda\right)$ and $\varphi_{a s}(k)$, were calculated using FEFF v. 8.00 [26]. The scale factor $\left(S_{\mathrm{c}}\right)$ and $\Delta E_{0}$ for $\mathrm{Zn}-\mathrm{N}(0.78,-16 \mathrm{eV})$ and $\mathrm{Zn}-\mathrm{S}(0.85,-16 \mathrm{eV})$ scattering were determined previously and held fixed throughout this analysis [25].[25, 27][25, 27] Fits to the current data were obtained for all reasonable integer or half-integer coordination numbers, refining only $R_{a s}$ and $\sigma_{\mathrm{as}}{ }^{2}$ for a given shell. Multiple scattering contributions from histidine ligands were approximated according to published procedures, fixing the number of imidazole ligands per metal ion at half-integral values while varying $R_{a s}$ and $\sigma_{\mathrm{as}}{ }^{2}$ for each of the four combined ms pathways (see Table 4) [25].

\section{Results}

\subsection{Determining optimal stress time with quantitative real-time PCR (qRT-PCR)}

In an effort to determine the optimal time for transcription of $\mathrm{Zn}$ (II)-responsive genes to begin, $E$. coli BW21135 cells were stressed with Zn(II) deficiency by using $10 \mu \mathrm{M}$ TPEN and harvested at various time points following the stress. The time-dependent transcription of most genes (znuA, zntA, zitB, and zupT), previously implicated in Zn(II) trafficking [1, $7,9,11,28-30]$ in $E$. coli or regulated by Zur (znuABC, ykgM and yodA) [17, 31], were evaluated by using qRT-PCR. The response of $z u r$-regulated genes $(z n u A, y k g M, y o d A)$ to TPEN was largest at 30 minutes, showing at least a 300 -fold increase for all genes (Figure 1). Previous cDNA array studies were conducted at 5 minutes and 5 hours $[16,17,31]$. Figure 1 shows that the transcription levels for the Zur-regulated genes at these times are approximately equal but are still over 100-fold less than at 30 minutes.

In contrast, the transcription levels of zupT, zntA, zitB, and control 16S RNA were not greatly affected by the presence of TPEN ( $\leq 4$-fold) (data not shown), suggesting that low levels of intracellular $\mathrm{Zn}$ (II) do not greatly affect the transcription of these genes. The absence of a strong response of $Z n t A$ to TPEN is consistent with previous studies on ZntR [16], which binds $\mathrm{Zn}(\mathrm{II})$ and activates production of the $\mathrm{Zn}(\mathrm{II})$ exporter $\mathrm{ZntA}$. In low $\mathrm{Zn}$ (II) conditions, $\mathrm{ZntR}$ does not bind to its promoter site or to $\mathrm{Zn}(\mathrm{II})$ and is degraded [32].

\section{2. cDNA microarrays}

The purpose for the aforementioned real-time PCR experiments was to determine the best time to harvest cells for cDNA microarray analysis of the $\mathrm{Zn}$ (II) starved condition. We prepared total RNA samples from E. coli that were stressed for 30 minutes with TPEN and completed the subsequent microarray studies. After filtering criteria were implemented (see Experimental procedures), 114 genes were found to be up-regulated, and 146 genes were down-regulated. The top 20 up-regulated genes are shown in Table 1. In our previous microarray studies, we identified 55 up-regulated transcripts [17], and $56 \%$ of these genes were also up-regulated in this study reported here. Most of the genes found in both studies are Zur- or Fur-regulated. All five Zur-regulated genes yodA, ykgM, znuA, znuB, and znuC were significantly $(\mathrm{P}<0.05)$ up-regulated in the cells stressed with TPEN for 30 minutes. Of 
the remaining up-regulated genes, $22 \%$ of them belong in the inorganic ion transport and metabolism COG (cluster of orthologous group) [33], 9\% have unknown function, $17 \%$ do not belong to an identified COG, and the remaining genes are spread among the other COG's (see Supplementary Materials).

Our previous microarray study only identified 46 down-regulated genes [17], while the current study revealed a 3 -fold increase in the number of down-regulated genes. The top 20 down-regulated genes are shown in Table 2. Only 32\% of the genes in the former study were identified in the current data, and most of the genes found in both studies are involved in flagella biosynthesis. ZntA, the high specificity exporter of $\mathrm{Zn}$ (II) [32], was down-regulated (5.6-fold), and this value is similar to that found in the qRT-PCR studies (ca. 4-fold drop). Of the remaining genes that were down-regulated in E. coli cells stressed for 30 minutes with TPEN, 33\% are members of the energy production and conversion COG, $16 \%$ belong to the cell motility COG flagella biosynthesis), $14 \%$ belong to the amino acid transport and metabolism COG, $5 \%$ are not a member of any identified $\mathrm{COG}$, and the remaining genes are spread among the other COG's [33] (see Supplementary Materials).

\subsection{Over-expression, purification, and characterization of $\mathrm{Zn}$ (II)-responsive proteins}

The three genes that exhibited the largest up-regulation in $\mathrm{Zn}$ (II) starvation conditions were $y k g M, \operatorname{yod} A$, and $z n u A$ (Table 1). We previously reported structural information on ZnuA [34], which is the periplasmic component of the ABC transporter ZnuABC that has been reported to be a high-specificity $\mathrm{Zn}(\mathrm{II})$ importer in $E$. coli. Our data and others show that $E$. coli ZnuA tightly binds 2 equivalents of $\mathrm{Zn}(\mathrm{II})$, and one of the sites has a single amino acid ligand identified $[34,35]$. The binding of $\mathrm{Zn}(\mathrm{II})$ causes a conformational change in the protein, which may be involved in $\mathrm{Zn}(\mathrm{II})$ transfer from ZnuA to the membrane-spanning ZnuB.

YodA is also a periplasmic protein and has been implicated in cadmium detoxification [36, 37]. We attempted to over-express and purify YodA from pET26b using BL21(DE3) E. coli cells, but the protein was not expressed at high levels, presumably due to the presence of 8 rare codons in the ORF of yodA [36]. The use of BL21-CodonPlus $®(D E 3)-R I P L$ or Rosetta $^{\mathrm{TM}}$ (DE3) E. coli cells did not result in better over-expression of the protein. However, the over-expression and purification of YodA was greatly improved if YodA was over-expressed as a maltose binding protein (MBP) fusion protein (MBP-YodA), and five milligrams of MBP-YodA could be purified per $1 \mathrm{~L}$ of LB growth medium. As isolated, MBP-YodA was found to bind 0.4 equivalents of $\mathrm{Zn}$ (II) per protein; yet, if the purified fusion protein was incubated with 10 molar equivalents of $\mathrm{Zn}$ (II) and dialyzed extensively versus $30 \mathrm{mM}$ Tris- $\mathrm{HCl}, \mathrm{pH}$ 7.6, the resulting protein bound $4.4 \pm 0.3$ equivalents of $\mathrm{Zn}$ (II). This result is in agreement with the crystal structure of YodA, which clearly showed four $\mathrm{Zn}(\mathrm{II})$ binding sites in the protein [36]. This result does not support a previous prediction that YodA binds only 2 of the $\mathrm{Zn}$ (II) ions tightly [15]. The physiological role of YodA is not clear; however, it has been hypothesized that YodA is part of an ABC transport system [36]. The $\mathrm{B}$ and $\mathrm{C}$ components of this putative $\mathrm{ABC}$ transporter have not yet been identified.

Our initial efforts to over-express, purify, and characterize YkgM involved cloning the gene for $y \mathrm{kgM}$ into pET26b. However, soluble YkgM could not be produced from this system. Therefore, YkgM was over-expressed as part of a MBP-fusion protein, and the resulting fusion protein was purified using a single affinity (amylose) column. This strategy yielded $70 \mathrm{mg}$ of $>90 \%$ pure protein per liter of growth medium. Thrombin cleavage of the fusion protein resulted in the precipitation of YkgM; therefore, we were forced to analyze the MBP-YkgM fusion protein for metal content. Metal analyses demonstrated that as-isolated MBP-YkgM binds less than 0.01 equivalents of $\mathrm{Zn}(\mathrm{II})$. The purified fusion protein was incubated with 10 molar equivalents of $\mathrm{Zn}(\mathrm{II})$, and the resulting mixture was dialyzed 
extensively versus metal-free, $25 \mathrm{mM}$ Tris-Cl, $\mathrm{pH} 7.6$, containing $200 \mathrm{mM} \mathrm{NaCl}$. The "metal-loaded" MBP-YkgM bound less than 0.01 equivalents of $\mathrm{Zn}(\mathrm{II})$.

\subsection{Over-expression, and purification of ribosomal protein L31}

As mentioned in the Introduction, $\mathrm{YkgM}$ is hypothesized to be a non-Zn(II) binding paralog of ribosomal protein L31. Using results on B. subtilis as an analogy, the $\mathrm{C}-\mathrm{YkgM}$ is produced in $\mathrm{Zn}$ (II) starvation conditions and replaces the $\mathrm{C}+\mathrm{L} 31$ on the ribosome, thereby releasing the $\mathrm{Zn}(\mathrm{II})$ bound to $\mathrm{L} 31$ [20, 38, 39]. To evaluate whether L31 is in fact a $\mathrm{Zn}$ (II)binding protein, the $L 31$ gene was ligated into pIAD14 [24], which resulted in the production of a MBP-L31 fusion protein. The greatest level of over-expressed MBP-L31 was obtained by allowing the bacterial cultures to grow to an O.D. $600 \mathrm{~nm}$ of $0.8-1.0$ before induction and by inducing protein production for 3 hours at $37^{\circ} \mathrm{C}$ with $0.2 \mathrm{mM}$ IPTG. Recombinant MBP-L31 was obtained by using a single affinity (amylose) column, and 70 $\mathrm{mg} / \mathrm{L}$ of $>95 \%$ pure protein was obtained. Efforts to remove the MBP tag resulted in irreversible protein precipitation.

Metal analyses demonstrated that MBP-L31, directly after purification, binds $0.3 \pm 0.1$ equivalents of $\mathrm{Zn}$ (II) (Table 3). No other metals were detected in significant amounts. To further probe for $\mathrm{Zn}$ (II) binding, MBP-L31 was incubated with up to 10 equivalents of $\mathrm{Zn}(\mathrm{II})$, and the resulting fusion protein was dialyzed versus 2 changes of $2 \mathrm{~L}$ of $25 \mathrm{mM}$ Tris$\mathrm{Cl}, \mathrm{pH} 7.6$, containing $200 \mathrm{mM} \mathrm{NaCl}$. The resulting, metal-loaded MBP-L31 was shown to bind $1.2 \pm 0.1$ equivalents of $\mathrm{Zn}$ (II) (Table 3).

\subsection{Site-directed mutants of MBP-L31}

Previous studies on B. subtilis have suggested a Zn(II) starvation system in which RpmE/ L31 (contains 4 Cys and is called the C+ protein) is replaced on the ribosome by its paralog YtiA (does not contain $\mathrm{Zn}$ (II)-binding Cys and is called the $\mathrm{C}$ - protein), and the $\mathrm{Zn}$ (II)bound to L31 is available to the cell in $\mathrm{Zn}$ (II) starvation conditions. Metal analyses on L31 and YkgM suggest that these proteins might play a similar role in E. coli. There are four cysteines in $E$. coli $\mathrm{L} 31$ at positions $16,18,37$, and 40 . To probe for metal binding cysteines in $E$. coli L31, single amino acid mutations were introduced at cysteine 16 and 18 to generate the C16S and C18S single mutants of MBP-L31. A double amino acid mutation was introduced at cysteine 37 and 40 to generate the C37/40S double mutant of MBP-L31. All the single and double mutants were over-expressed, purified, and shown to be isolated as soluble fusion proteins at yields similar to those of the wild-type fusion proteins. Metal analyses on the MBP-L31 mutants were conducted to probe whether any of these cysteines participate in metal binding. The as-isolated recombinant C16S mutant contained no $\mathrm{Zn}$ (II) (Table 3). The C16S mutant was incubated with 10 equivalents of $\mathrm{Zn}(\mathrm{II})$, and the resulting protein solution was exhaustively dialyzed versus 2 changes of 2 liters of $25 \mathrm{mM}$ Tris-Cl, $\mathrm{pH} 8.5$, containing $200 \mathrm{mM} \mathrm{NaCl}$. The "metal-loaded" C16S mutant contained $0.4 \pm 0.1$ equivalents of $\mathrm{Zn}(\mathrm{II})$ (Table 3). The as-isolated C18S mutant contained no $\mathrm{Zn}$ (II) (Table 3), and the "metal-loaded" C18S mutant bound $1.1 \pm 0.1$ equivalents of $\mathrm{Zn}$ (II) (Table 3). The as-isolated C37/40S double mutant contained $0.4 \pm 0.1$ equivalents of $\mathrm{Zn}$ (II), and the "metal-loaded" C37/40S double mutant bound $1.3 \pm 0.1$ equivalents of $\mathrm{Zn}(\mathrm{II})$ (Table 3).

\subsection{EXAFS of MBP-L31}

In an effort to characterize the metal binding site of MBP-L31, the Zn(II)-supplemented analog of MBP-L31 was examined using X-ray absorption spectroscopy (Figure 2, top). The data (solid, black line) is best modeled (open symbols) with four donors in the primary coordination sphere of the $\mathrm{Zn}$ (II), only one of which is sulfur (Figure 2, top, and Table 4; detailed fits are presented in Figure S1 and Table S1). Multiple scattering fits that model the 
outer shell scattering of coordinated imidazole suggest that only one ligand is a histidine side chain, leaving the other two as either backbone amides or solvent.

A nearly identical picture arises when examining the EXAFS of the C37/40S double-mutant. A direct comparison of the EXAFS FTs (Figure 2, center) shows that the main peak is significantly higher in magnitude, which could reflect a slightly higher coordination number for the mutant. All of the outer shell features are nearly identical, although again the two outermost peaks are slightly higher in magnitude. Despite these small cosmetic differences, the data for the mutant are best fitted with the same model as the recombinant protein (Figure 2, bottom, and Table 4; detailed fits are presented in Table S1 and Figure S2), including a single sulfur donor in the primary coordination sphere and one coordinated imidazole. What is clear from the EXAFS is that the mutations failed to significantly alter the metal binding site.

\section{Discussion}

In an effort to understand intracellular Zn(II) homeostasis in E. coli, we and others performed proteomic and genomic studies to probe for Zn(II)-responsive proteins [13-18], reasoning that some of the proteins that were up-regulated during $\mathrm{Zn}$ (II) starvation would be involved with $\mathrm{Zn}$ (II) import, trafficking, and possibly export. While there have been great advances in cDNA array technology that make it much easier and more economical to use, the duration of the stress and type of microarray chip used remains common problems when comparing data from different cDNA microarray experiments. For any given experiment, the timing of the stress is often chosen arbitrarily. For cDNA microarrays to be performed at a vast number of time points as well as conditions introduces an enormous amount of time and expense into the equation. In previous DNA array experiments, we reported 55 upregulated and 46 down-regulated genes in response to $5 \mathrm{hr}$ of TPEN stress [17]. It is possible that some transcripts, such as those encoding for other $\mathrm{Zn}(\mathrm{II})$ transport systems such as ZitB, ZupT, and possibly ZraP, may not have exhibited differential expression because of the long stress time. One major objective of this present work was to determine an optimal time in which to perform cDNA microarray experiments when examining the effect of $\mathrm{Zn}$ (II) deficiency and excess on transcription in E. coli.

qPCR studies demonstrated that the expression of Zur-regulated genes up-regulated by low $\mathrm{Zn}$ (II) conditions is maximal at 30 minutes (Figure 1). Using 30 minutes of TPEN stress, we observed 114 up- and 146 down-regulated, $\mathrm{Zn}(\mathrm{II})$-responsive genes in DNA array experiments. Many of them were observed previously [17], such as znuA, $y \mathrm{kgM}$, yodA, and many Fur-regulated genes were up-regulated. In this work, we report two additional genes that are up-regulated by $\mathrm{Zn}$ (II)-starvation that are in the same gene clusters as $\operatorname{yod} A$ and $z n u A$ and could possibly be regulated by Zur. The first of these is $\operatorname{yodB}$, an integral membrane protein that is a predicted cytochrome, which is located directly downstream of yod $A$ in the $E$. coli chromosome. The other Zur-regulated candidate, yebA, is located directly downstream of $z n u A$, a known Zur-regulated protein. Neither of these genes have been studied in enough detail to know if the proteins that they encode could possibly be involved in $\mathrm{Zn}$ (II) homeostasis and thus will be a target of future research. It is noteworthy that regulation of the other known and putative $\mathrm{Zn}$ (II) transporters is not observed here, other than for that of the exporter $z n t A$ gene (down 5.7-fold), which is transcriptionallyregulated by ZntR. The most likely reason for this result is that ZnuABC is the most important importer of $\mathrm{Zn}$ (II) at low $\mathrm{Zn}$ (II) conditions. It is also likely that intracellular $\mathrm{Zn}$ (II) levels are controlled primarily by import, rather than export, at least under $\mathrm{Zn}$ (II)-limiting conditions. 
The cDNA array study did reveal, in agreement with our previous study [17], that the most up-regulated genes were $y \mathrm{kgM}$, yodA, and $z n u A$. We previously reported structural and metal binding studies on ZnuA, and ZnuA is known to be the periplasmic component of the high affinity $\mathrm{Zn}(\mathrm{II})$ importer ZnuABC [34]. The transcription of $z n u A B C$ is under control of Zur, and under low $\mathrm{Zn}$ (II) conditions, high levels of ZnuABC are produced, and $\mathrm{Zn}$ (II) is imported from the periplasm of $E$. coli into the cytoplasm [31]. Previous studies showed that ZnuA can "pull" $\mathrm{Zn}$ (II) from other $\mathrm{Zn}$ (II)-containing periplasmic proteins [40]. The reason that $z n u A$ (and $z n u B, C$ ) is up-regulated in our studies is clear.

The transcription of $\operatorname{yod} A$ is also under control of Zur [37], and its up-regulation during $\mathrm{Zn}$ (II)-deficient conditions is not surprising. Nonetheless, it is not clear exactly what role YodA plays in Zn(II) homeostasis. Previously, it was hypothesized that YodA was part of an $\mathrm{ABC}$ transporter system, like ZnuABC; however, the BC components of this system have not been identified [36]. Complicating this issue further is the previous suggestion that YodA is involved with $\mathrm{Cd}(\mathrm{II})$ homeostasis, possibly detoxification, and one crystal structure of YodA was obtained with 4 equivalents of $\mathrm{Cd}(\mathrm{II})$ bound [36, 37]. The crystal structure of $\mathrm{Zn}$ (II)-bound YodA was also reported, and this structure showed $4 \mathrm{Zn}$ (II) binding sites in YodA: (1) one $\mathrm{Zn}$ (II) coordinated by His144 and His 155 (and two solvent molecules), (2) a second Zn(II) coordinated by His153, Glu189, and His193, (3) a third Zn(II) coordinated only by one protein ligand (His95), and (4) a fourth $\mathrm{Zn}(\mathrm{II})$ coordinated by only one protein ligand (Asp24) [36]. It was predicted that under physiological conditions that YodA only binds $2 \mathrm{Zn}$ (II) ions tightly [15]. To test this hypothesis, we over-expressed and purified YodA. Due to solubility issues, we were forced to obtain YodA as a fusion protein with MBP. Metal analyses showed that YodA tightly binds 4 equivalents of $\mathrm{Zn}(\mathrm{II})$. We have attempted pulldown experiments in an effort to identify some periplasmic proteins with which YodA might interact, and several outer membrane proteins were identified [41]. However, none of the identified proteins help to explain the role of YodA in Zn(II) transport/homeostasis.

The most up-regulated gene in our studies was $y \mathrm{kgM}$. Since the transcription of $y \mathrm{kgM}$ is under control of Zur [19], it is not surprising that the gene was up-regulated. In response to $\mathrm{Zn}$ (II) starvation, a $\mathrm{Zn}$ (II) mobilization model, called $\mathrm{C}+/ \mathrm{C}-$, has been proposed in $B$. subtilis, and this model has been discussed (vide supra) [19]. It has been proposed that a similar system is in place in $E$. coli, and $\mathrm{YkgM}(\mathrm{C}-) / \mathrm{L} 31(\mathrm{C}+)$ were identified as a possible paralogous pair. In support of this proposal is our hypothesis that the ribosomes in E. coli store $\mathrm{Zn}(\mathrm{II})$ [42], and the recent confirmation that $E$. coli ribosome tightly binds up to 8 equivalents of $\mathrm{Zn}$ (II) (M.P. Hensley and M.W. Crowder, unpublished data). To further support the hypothesis that a $\mathrm{C}+/ \mathrm{C}-$ minus system is in place in $E$. coli, we over-expressed and purified $\mathrm{YkgM}$ and its putative paralog $\mathrm{L} 31$.

As with YodA, we could only obtain soluble YkgM and L31 as fusion proteins with MBP. Metal analyses demonstrate that $\mathrm{YkgM}$ does not bind $\mathrm{Zn}(\mathrm{II})$ and that $\mathrm{L} 31$ binds one equivalent of $\mathrm{Zn}(\mathrm{II})$, supporting the hypothesis that these proteins are paralogs. MBP-L31 was shown to bind 1 equivalent of $\mathrm{Zn}(\mathrm{II})$. Previously from the studies on RpmE/YtiA in $B$. subtilis, it was hypothesized that RpmE binds $\mathrm{Zn}$ (II) through 2-4 cysteine residues; these same residues are not found in the paralog YtiA and hence the name, C-protein [19, 20]. To probe whether $\mathrm{Zn}$ (II) binds any of the Cys residues in L31, EXAFS studies on the Zn(II)supplemented analog of L31 were conducted. The best fit to the data suggests that $\mathrm{Zn}$ (II) binds only 1 Cys, 1 His, and 2 other low-Z (N/O) ligands. In addition, the site-directed mutagenesis data suggests that only Cys 16 takes part in binding.

An examination of the crystal structure of $\mathrm{L} 31$ bound to the E. coli 50S ribosome shows that L31 binds over $100 \AA$ A from the exit tunnel (measuring the distance between Leu51 in L24 
and Cys40 in L31) (Figure 3(A)). Focusing on the structure of bound L31 (Figure 3(B)), the sulfur atoms in Cys37 and Cys40 are $4.4 \AA$ apart; however, the atoms are not facing each other perfectly for metal binding. Cys 37 and Cys 40 are $45 \AA$ away from Cys 16 and Cys 18 , which have their sulfur atoms almost $11 \AA$ apart. From this structure, it is clear to see that it is impossible for all four cysteines to coordinate $\mathrm{Zn}(\mathrm{II})$ in $\mathrm{L} 31$ when it is bound to the ribosome (Figure 3 (C and D)). Given this structure, it would appear that $\mathrm{Zn}$ (II) would more likely to bind in between Cys37 and Cys40; however, there is no electron density in between these cysteines in any of the E. coli ribosome crystal structures that were examined, possibly because of the inclusion of EDTA and high levels of $\mathrm{Mg}(\mathrm{II})$ in buffers used when purifying E. coli ribosomes. While in solution, it appears that L31 binds to Cys 16 and possibly His 30 (the closest His to Cys16 - $23 \AA$ away), which would cause a major structural change in the protein when not bound to the ribosome. It is not clear if $\mathrm{Zn}$ (II) binds to the same site when L31 is bound to the ribosome.

When examining many crystal structures of the $E$. coli ribosome for potential $\mathrm{Zn}(\mathrm{II})$ binding sites, we discovered L36, which is a small protein that binds to the large subunit. Previous NMR solution studies on L36 from T. thermophilus, showed that $\mathrm{Zn}(\mathrm{II})$ is bound by a common Zn finger motif, consisting of Cys27, His32, Cys11, and Cys14 (Figure 5) [43]. In a recent structure of the E. coli ribosome bound to an antibiotic, L36 was found to bind $\mathrm{Zn}$ (II) even when the ribosomes were purified using high levels of EDTA [44]. L36 is $158 \AA$ away from the exit tunnel of the large subunit, and $\mathrm{Zn}(\mathrm{II})$ is coordinated by Cys11, Cys14, Cys27, and His33 (Figure 4). Interestingly, the Zn(II) binding ligands in both structures do not point directly at the $\mathrm{Zn}(\mathrm{II})$, and the metal-ligand distances are $2.26-2.47 \AA$ (see Figure 4).

Therefore, L36 appears to be a better C+ candidate in E. coli (and Thermus). To be part of a $\mathrm{C}+/ \mathrm{C}$ - system however, there should be a $\mathrm{C}$ - paralog present in $E$. coli. A potential candidate is $\mathrm{YkgO}$, which is transcriptionally-regulated by Zur and is part of the $y \mathrm{kgM} /$ $y \mathrm{kgO}$ operon [45]. We did not observe the up-regulation of the $y \mathrm{kgO}$ gene because this gene is not included in the Affymetrix gene chips used in these studies. Future studies will involve testing whether $\mathrm{L} 36$ and $\mathrm{YkgO}$ are $\mathrm{Zn}$ (II)-responsive paralogs.

\section{Supplementary Material}

Refer to Web version on PubMed Central for supplementary material.

\section{Acknowledgments}

This work was funded by the National Institutes of Health (GM079411 and GM093987), Miami University's Committee on Faculty Research, and Miami University's Volwiler professorship (to M.W.C.).

\section{Abbreviations}
COG
clusters of orthologous groups
RT-PCR
real-time polymerase chain reaction
TPEN
$\mathrm{N}, \mathrm{N}, \mathrm{N}, \mathrm{N}^{\prime}$-tetrakis(2-pyridylmethyl)ethylenediamine

\section{References Cited}

1. Hantke K. Curr. Opin. Microbiol. 2005; 8:196-202. [PubMed: 15802252]

2. Vallee BL, Auld DS. Proc. Natl. Acad. Sci. 1990; 87:220-224. [PubMed: 2104979]

3. Vallee BL, Auld DS. Biochemistry. 1990; 29:5647-5659. [PubMed: 2200508] 
4. Vallee, BL.; Auld, DS.; Joiles, P.; Jornvall, H., editors. Interface between Chemistry and Biochemistry. Basel, Switzerland: Birkhauser Verlag; 1995. p. 259-277.

5. Hantke K. Curr. Opin. Microbiol. 2001; 4:172-177. [PubMed: 11282473]

6. Lu M, Fu D. Science. 2007; 317:1746-1748. [PubMed: 17717154]

7. Hantke K. Biometals. 2001; 14:239-249. [PubMed: 11831459]

8. Outten CE, O'Halloran TV. Science. 2001; 292:2488-2492. [PubMed: 11397910]

9. Grass G, Fan B, Rosen BP, Franke S, Nies DH, Rensing C. J. Bacteriol. 2001; 183:4664-4667. [PubMed: 11443104]

10. Outten CE, Tobin DA, Penner-Hahn JE, O'Halloran TV. Biochemistry. 2001; 40:10417-10423. [PubMed: 11523983]

11. Grass G, Wong MD, Rosen BP, Smith RL, Rensing C. J. Bacteriol. 2002; 184:864-866. [PubMed: 11790762]

12. Jackson RJ, Binet MR, Lee LJ, Ma R, Graham AI, McLeod CW, Poole RK. FEMS Microbiol Lett. 2008; 289:219-224. [PubMed: 19054109]

13. Brocklehurst KR, Morby AP. Microbiology. 2000; 146:2277-2282. [PubMed: 10974115]

14. Lee LJ, Barrett JA, Poole RK. J. Bacteriol. 2005; 187:1124-1134. [PubMed: 15659689]

15. Graham AI, Hunt S, Stokes SL, Bramall N, Bunch J, Cox AG, McLeod CW, Poole RK. J. Biol. Chem. 2009; 284:18377-18389. [PubMed: 19377097]

16. Yamamoto K, Ishihama A. J. Bacteriol. 2005; 187:6333-6340. [PubMed: 16159766]

17. Sigdel TK, Easton JA, Crowder MW. J. Bacteriol. 2006; 188:6709-6713. [PubMed: 16952965]

18. Easton JA, Thompson P, Crowder MW. J. Biomol. Tech. 2006; 17:303-307. [PubMed: 17122063]

19. Nanamiya H, Akanuma G, Natori Y, Murayama R, Kosono S, Kudo T, Kobayashi K, Ogawawara N, Park S-M, Ochi K, Kawamura F. Molec. Microbiol. 2004; 52:273-283. [PubMed: 15049826]

20. Natori Y, Nanamiya H, Akanuma G, Kosono S, Kudo T, Ochi K, Kawamura F. Mol. Microbiol. 2007; 63:294-307. [PubMed: 17163968]

21. Panina EM, Mironov AA, Gelfand MS. Proc. Natl. Acad. Sci. 2003; 100:9912-9917. [PubMed: 12904577]

22. Rajagopalan PTR, Grimme S, Pei D. Biochemistry. 2000; 39:779-790. [PubMed: 10651644]

23. Gunasekera TS, Csonka LN, Paliy O. J. Bacteriol. 2008; 190:3712-3720. [PubMed: 18359805]

24. McCafferty DG, Lessard IAD, Walsh CT. Biochemistry. 1997; 36:10498-10505. [PubMed: 9265630]

25. Thomas PW, Stone EM, Costello A, Tierney DL, Fast W. Biochemistry. 2005; 44:7559-7569. [PubMed: 15895999]

26. Ankudinov AL, Ravel B, Rehr JJ, Conradson SD. Phys. Rev. B. 1998; 58:7565-7576.

27. Periyannan G, Costello AL, Tierney DL, Yang KW, Bennett B, Crowder MW. Biochemistry. 2006; 45:1313-1320. [PubMed: 16430228]

28. Beard SJ, Hashim R, Wu G, Binet MRB, Hughes MN, Poole RK. FEMS Microbiol. Lett. 2000; 184:231-235. [PubMed: 10713426]

29. Blencowe DK, Morby AP. FEMS Microbiol. Lett. 2003; 27:291-311.

30. Chimienti F, Aouffen M, Favier A, Seve M. Curr. Drug Targets. 2003; 4:323-338. [PubMed: 12699353]

31. Patzer SI, Hantke K. Mol. Microbiol. 1998; 28:1199-1210. [PubMed: 9680209]

32. Rensing C, Mitra B, Rosen BP. Proc. Natl. Acad. Sci. 1997; 94:14326-14331. [PubMed: 9405611]

33. Tatusov RL, Natale DA, Garkavtsev IV, Tatusova TA, Shankavaram UT, Rao BS, Kiryutin B, Galperin MY, Fedorova ND, Koonin EV. Nucleic Acid Res. 2001; 29:22-28. [PubMed: 11125040]

34. Yatsunyk LA, Easton JA, Kim LR, Sugarbaker SA, Bennett B, Tierney DL, Crowder MW, Rosenzweig AC. J. Biol. Inorg. Chem. 2008; 13:271-288. [PubMed: 18027003]

35. Ammendola S, Pasquali P, Pistoia C, Petrucci P, Petrarca P, Rotilio G, Battistoni A. Infect. Immun. 2007; 75:5867-5876. [PubMed: 17923515]

36. David G, Blondeau K, Schiltz M, Penel S, Lewit-Bentley A. J. Biol. Chem. 2003; 278:4372843735. [PubMed: 12909634] 
37. Puskarova A, Ferianc P, Kormanec J, Homerova D, Farewell A, Nystrom T. Microbiology. 2002; 148:3801-3811. [PubMed: 12480884]

38. Nanamiya H, Akanuma G, Natori Y, Murayama R, Kosono S, Kudo T, Kobayashi K, Ogasawara N, Park SM, Ochi K, Kawamura F. Mol Microbiol. 2004; 52:273-283. [PubMed: 15049826]

39. Nanamiya H, Kawamura F, Kosono S. J. Gen. Appl. Microbiol. 2006; 52:249-258. [PubMed: 17310068]

40. Berducci G, Mazzetti AP, Rotilio G, Battistoni A. FEBS Lett. 2004; 569:289-292. [PubMed: 15225650]

41. Sigdel, TK. A search for $\mathrm{Zn}$ (II) metallochaperones in E. coli, proteomic and genomic approaches. Ph.D. Oxford, OH: Miami University; 2005.

42. Gunasekera, TS.; Easton, JA.; Sugarbaker, SA.; Klingbeil, L.; Crowder, MW. Zn(II) homeostasis in E. coli. In: Long, EC.; Baldwin, MJ., editors. Bioinorganic chemistry: Cellular systems and synthetic models. Washington, D.C: American Chemical Society; 2009. p. 81-93.

43. Hard T, Rak A, Allard P, Kloo L, Garber M. J. Mol. Biol. 2000; 296:169-180. [PubMed: 10656825]

44. Dunkle JA, Xiong L, Mankin AS, Cate JH. Proc. Natl. Acad. Sci. 2010; 107:17152-17157. [PubMed: 20876128]

45. Hemm MR, Paul BJ, Miranda-Rios J, Zhang A, Soltanzad N, Storz G. J. Bacteriol. 2010; 192:4658. [PubMed: 19734316]

46. Kehres DG, Zaharik ML, Finlay BB, Maguire ME. Mol. Microbiol. 2000; 36:1085-1100. [PubMed: 10844693]

47. Gehring AM, Mori I, Walsh CT. Biochemistry. 1998; 37:2648-2659. [PubMed: 9485415]

48. Escolar L, Perez-Martin J, de Lorenzo V. J. Bacteriol. 1998; 180:2579-2582. [PubMed: 9573216]

49. Vanderkelen L, Van Herreweghe JM, Vanoirbeek KG, Baggerman G, Myrnes B, Declerck PJ, Nilsen IW, Michiels CW, Callewaert L. Cell. Mol. Life Sci. 2011; 68:1053-1064. [PubMed: 20734102]

50. Hunt MD, Pettis GS, McIntosh M. J. Bacteriol. 1994; 176:3944-3955. [PubMed: 8021177]

51. Chen D, Wu R, Bryan TL, Dunaway-Mariano D. Biochemistry. 2009; 48:511-513. [PubMed: 19119850]

52. Liu J, Quinn N, Berchtold GA, Walsh CT. Biochemistry. 1990; 29:1417-1425. [PubMed: 2139795]

53. Strahsburg E, Baeza M, Monasterio O, Lagos R. Antimicro. Agents Chemo. 2005; 49:3083-3086.

54. Sauer M, Hantke K, Braun V. J. Bacteriol. 1987; 169:2044-2049. [PubMed: 3032906]

55. Panina EM, Mironov AA, Gelfand MS. Nucleic Acid Res. 2001; 29:5195-5206. [PubMed: 11812853]

56. Rusnak F, Sakaitani M, Drueckhammer D, Reichert J, Walsh CT. Biochemistry. 1991; 30:29162927. [PubMed: 1826089]

57. Liu J, Duncan K, Walsh CT. J. Bacteriol. 1989; 171:791-798. [PubMed: 2521622]

58. Braun V, Braun M. FEBS Lett. 2002; 529:78-85. [PubMed: 12354617]

59. Hopkin K, Papazian M, Steinman H. J. Biol. Chem. 1992; 267:24253-24258. [PubMed: 1447175]

60. Rodrigue A, Effantin G, Mandrand-Berthelot MA. J. Bacteriol. 2005; 187:2912-2916. [PubMed: 15805538]

61. Cheng VW, Ma E, Zhao Z, Rothery RA, Weiner JH. J. Biol. Chem. 2006; 281:27662-27668. [PubMed: 16864590]

62. Kiley PJ, Beinert H. Curr. Opin. Microbiol. 2003; 6:181-185. [PubMed: 12732309]

63. Flint DH. Arch. Biochem. Biophys. 1994; 311:509-516. [PubMed: 8203917]

64. Hussain H, Grove J, Griffiths L, Lusby S, Cole J. Mol. Microbiol. 1994; 12:153-163. [PubMed: 8057835]

65. Letoffe S, Delepelaire P, Wandersman C. Proc. Natl. Acad. Sci. 2006; 103:12891-12896.

[PubMed: 16905647]

66. Ding H, Clark RJ, Lu K. J. Biol. Chem. 2004; 279:37499-37504. [PubMed: 15247288]

67. Tu AH, Turnbough CL. J. Bacteriol. 1997; 179:6665-6673. [PubMed: 9352914] 
68. Mihara H, Hidese R, Yamane M, Kurihara T, Esaki N. Biochem. Biophys. Res. Comm. 2008; 372:407-411. [PubMed: 18482579]

69. McNicholas PM, Gunsalus RP. J. Bacteriol. 2002; 184:3253-3259. [PubMed: 12029041]

70. Woods SA, Schwartzbach SD, Guest JR. Biochim. Biophys. Acta. 1988; 954:14-26. [PubMed: 3282546]

71. Matsushita K, Ohnishi T, Kaback HR. Biochemistry. 1987; 26:7732-7737. [PubMed: 3122832] 

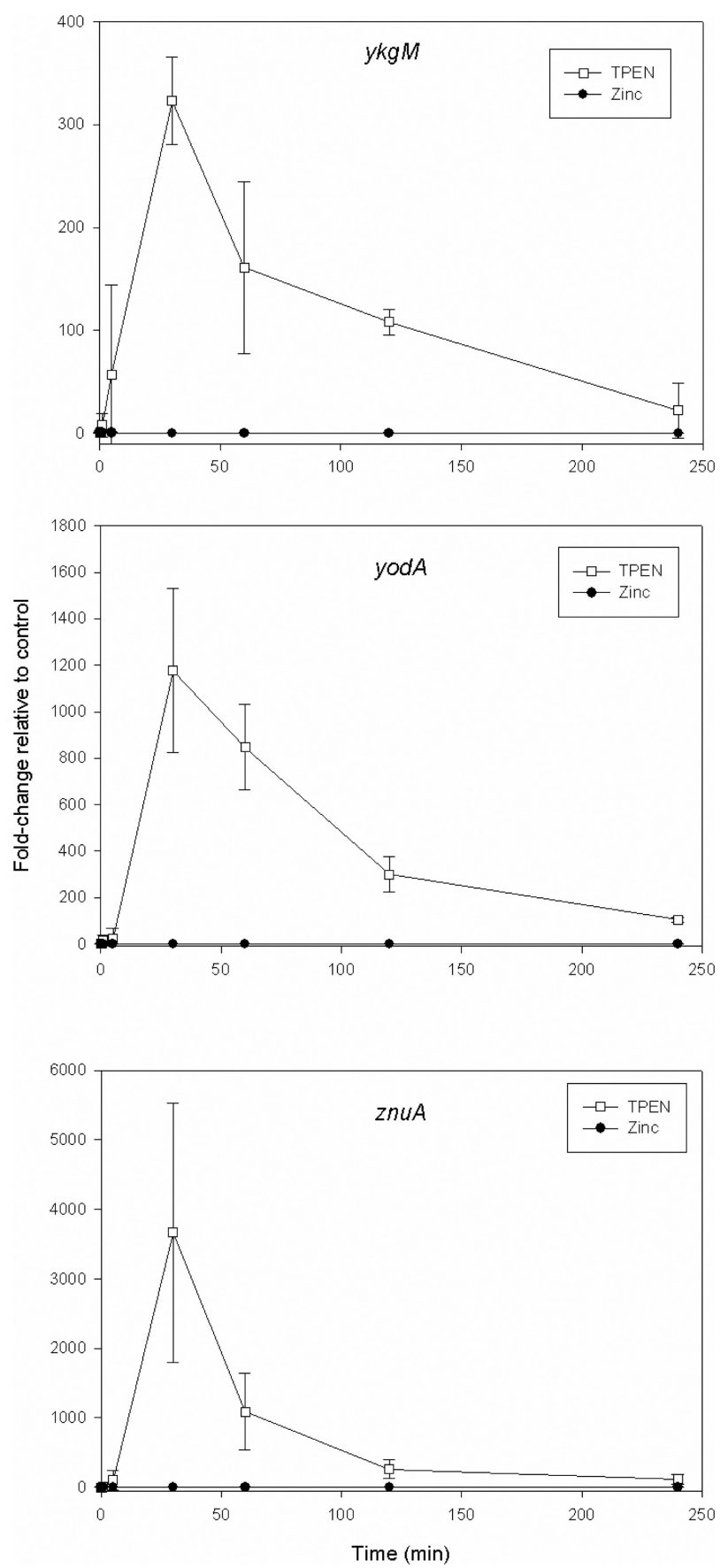

Figure 1.

Time-dependent real-time PCR of Zur-regulated genes. 


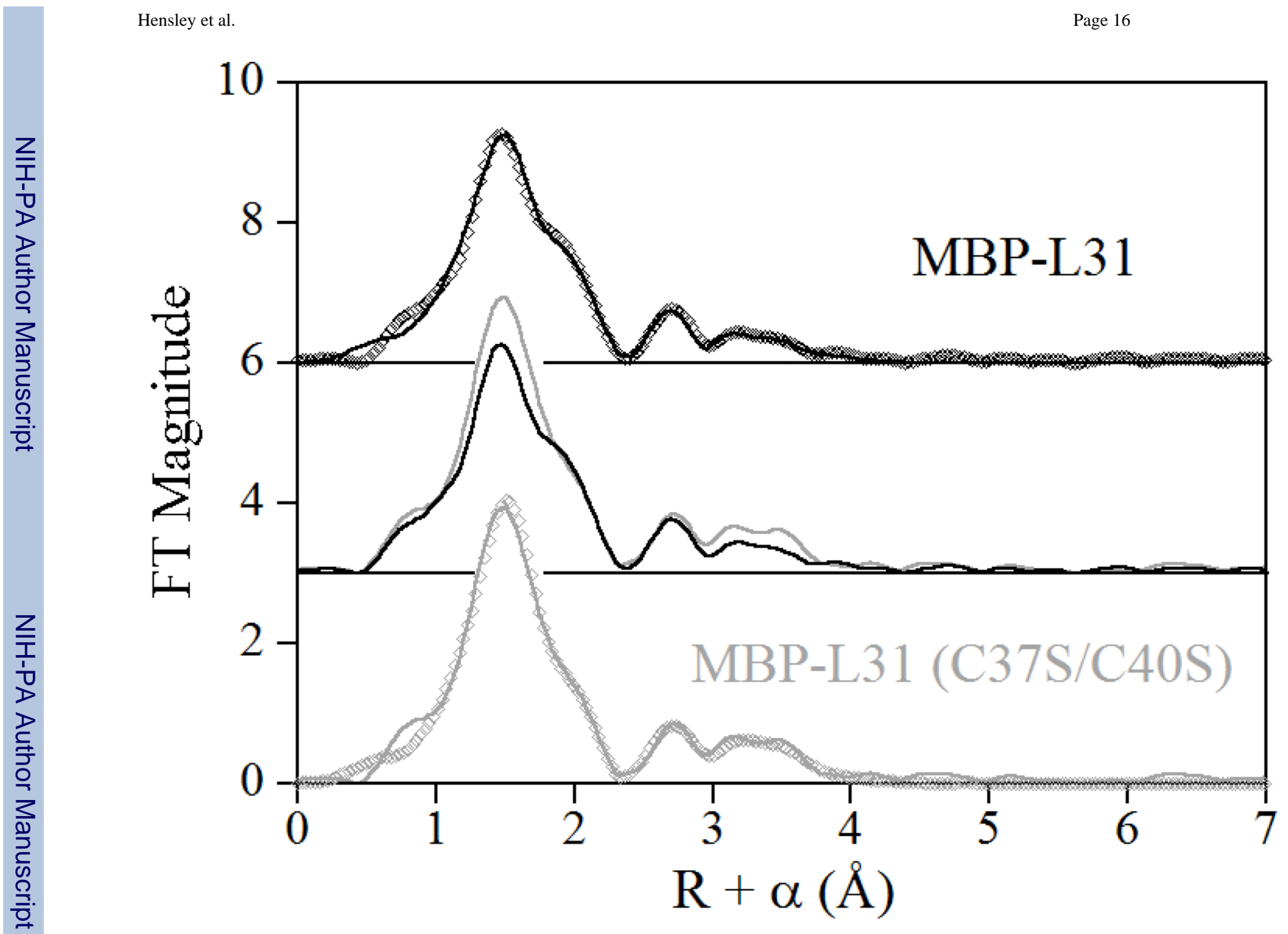

Figure 2.

EXAFS Fourier transforms for Zn(II)-supplemented MBP-L31 (black) and the C37S/C40S double mutant (gray). 

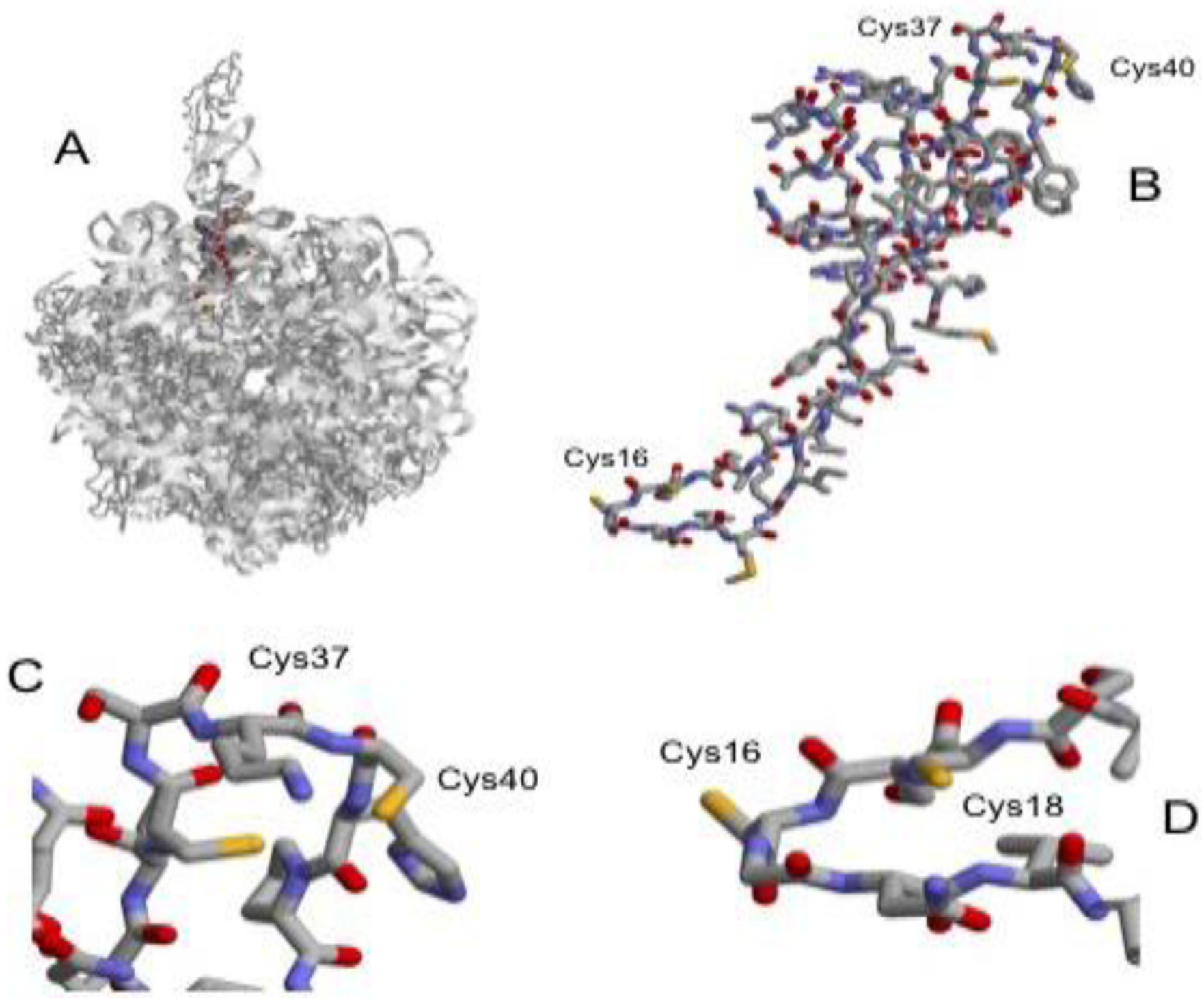

Crystal structure of L31. (A) L31 bound to E. coli ribosome. (B) E. coli L31. (C) Site one of L31 containing Cys37 and Cys40. (D) Site two of L31 containing Cys16 and Cys18. 

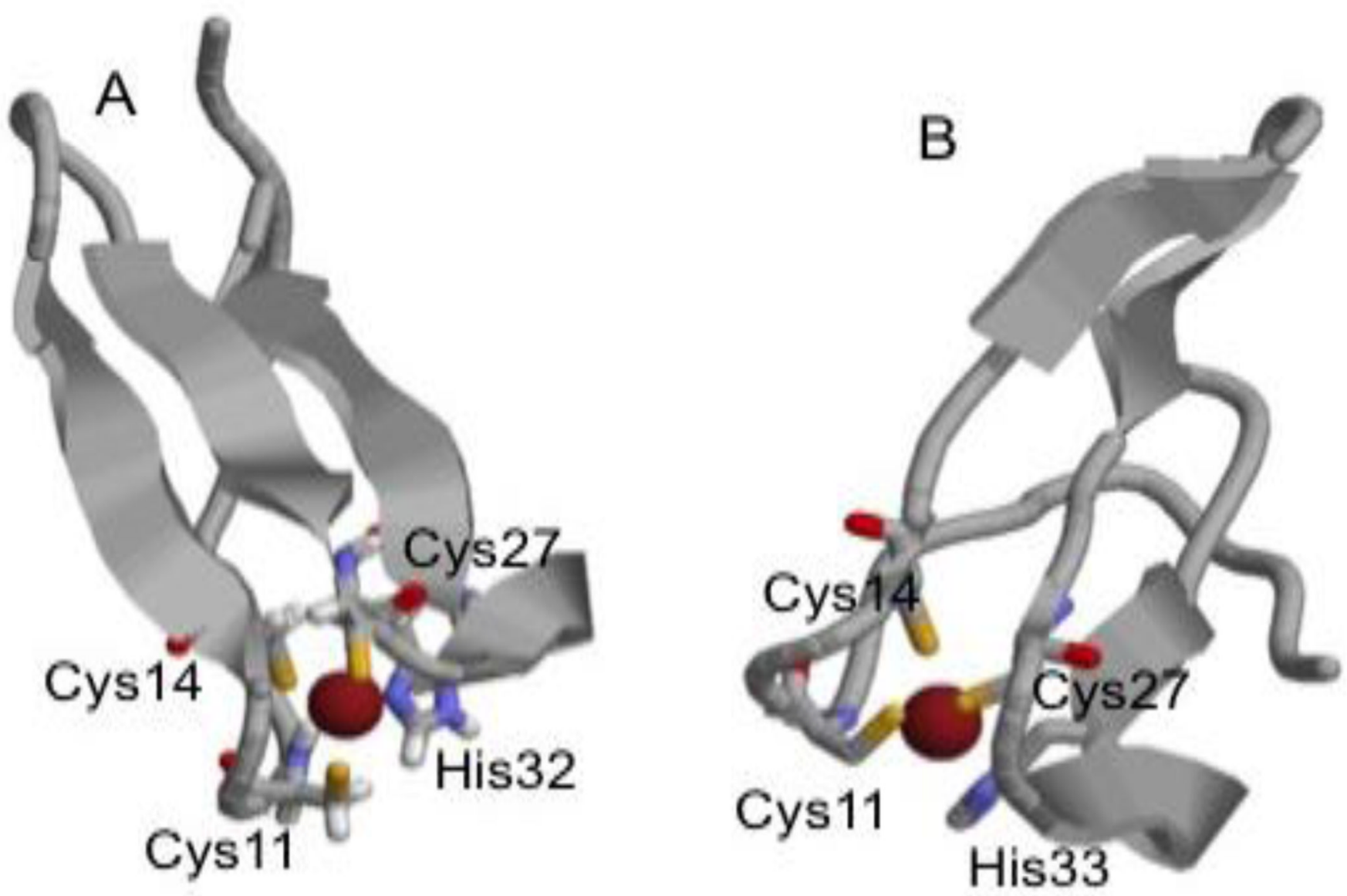

Figure 4.

Structures of L36: (A) T. thermophilus L36 (NMR; [43]) and (B) E. coli L36 (crystal structure; [44]) 


\begin{tabular}{|c|c|c|c|c|c|c|c|c|c|c|c|c|c|c|c|c|c|c|c|c|c|}
\hline & $\overline{\mathscr{\Xi}}$ & $\Xi$ & \begin{tabular}{l}
$\overline{0}$ \\
\hdashline
\end{tabular} & F & 守 & 守 & $\bar{\Xi}$ & 京 & $\overline{\bar{g}}$ & $\bar{\Omega}$ & $\bar{\Xi}$ & $\overline{\bar{\sigma}}$ & 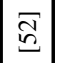 & $\overline{\tilde{\Omega}}$ & 胥 & $\begin{array}{l}\bar{n} \\
\underline{n}\end{array}$ & 荤 & $\begin{array}{l}\overline{0} \\
\stackrel{n}{n}\end{array}$ & $\bar{n}$ & 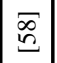 & 离 \\
\hline & 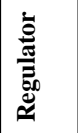 & $\stackrel{\Xi}{N}$ & 心 & $\stackrel{\Xi}{\text { N }}$ & 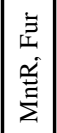 & 言 & 言 & 言 & $\sigma$ & 童 & 量 & 童 & 言 & 言 & 㪯 & 童 & 麦 & 言 & 言 & 言 & 竞 \\
\hline & 흥 & 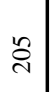 & \begin{tabular}{l}
$\infty$ \\
\hdashline \\
-
\end{tabular} & F & $m$ & $\vec{N}$ & & $\cong$ & $\simeq$ & $=$ & $?$ & $\circ$ & $\circ$ & $\stackrel{\infty}{\circ}^{\infty}$ & $\stackrel{\Delta}{\circ}$ & m & $\begin{array}{l}\infty_{\infty} \\
\infty\end{array}$ & $\infty$ & $\stackrel{2}{\therefore}$ & $\stackrel{?}{?}$ & $\stackrel{?}{r}$ \\
\hline & 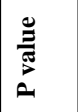 & 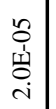 & 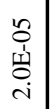 & 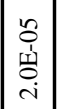 & $\mid \begin{array}{l}0 \\
0 \\
\text { 离 } \\
\text { in }\end{array}$ & $\begin{array}{l}n \\
o \\
1 \\
\infty \\
\infty \\
\sigma\end{array}$ & $\mid \begin{array}{l}0 \\
0 \\
0 \\
0 \\
i \\
i\end{array}$ & 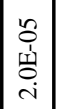 & 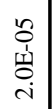 & 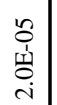 & 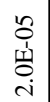 & 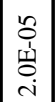 & 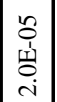 & 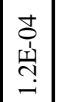 & 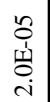 & 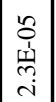 & 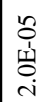 & 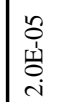 & 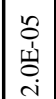 & 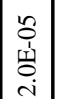 & 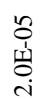 \\
\hline 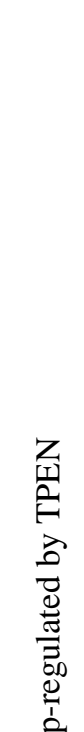 & 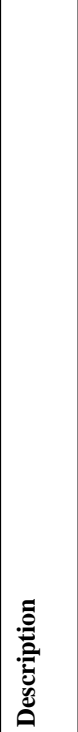 & 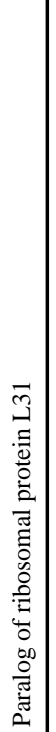 & 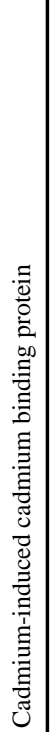 & 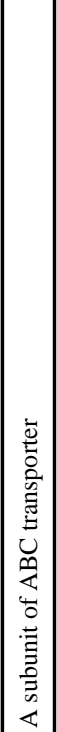 & 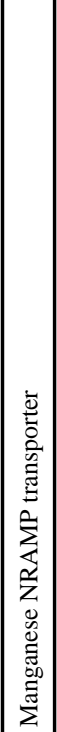 & 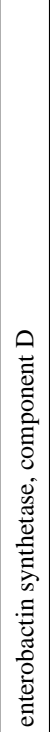 & 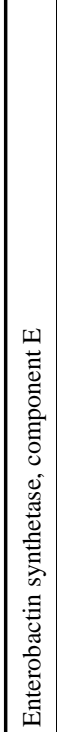 & 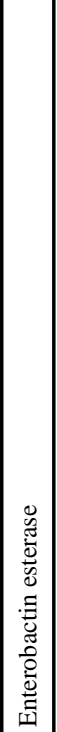 & 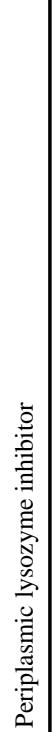 & 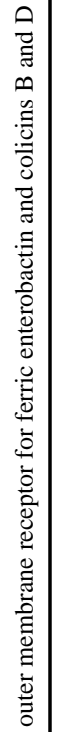 & 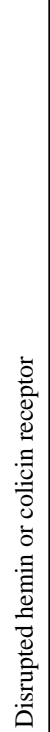 & 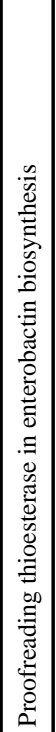 & 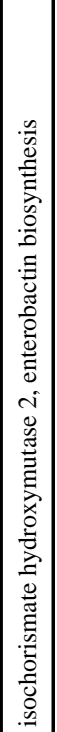 & 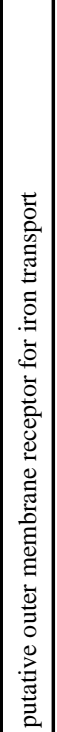 & 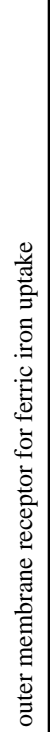 & 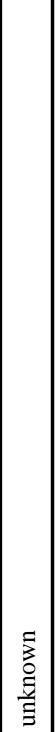 & 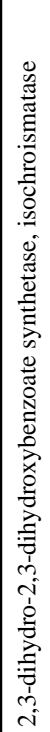 & \begin{tabular}{|c} 
\\
\\
\\
\end{tabular} & 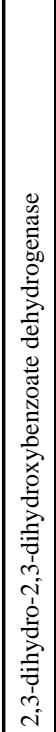 & 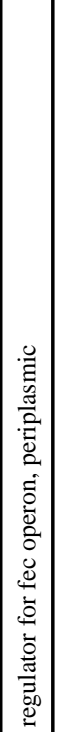 & 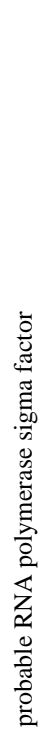 \\
\hline 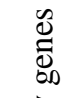 & $\approx$ & $\begin{array}{l}\text { ¿े } \\
\text { ळे }\end{array}$ & $\frac{\hat{a}}{\hat{m}}$ & $\mid \begin{array}{l}\infty \\
\infty \\
\infty \\
\infty\end{array}$ & 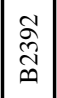 & 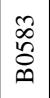 & 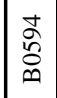 & \begin{tabular}{|c|c|}
$\infty$ \\
$\infty$ \\
$o$ \\
$\infty$ \\
$\infty$
\end{tabular} & $\stackrel{\infty}{\stackrel{\infty}{=}}$ & $\mid$\begin{tabular}{l}
1 \\
0 \\
0 \\
0 \\
\hdashline
\end{tabular} & $\frac{n}{\frac{\alpha}{\infty}}$ & 鸽 & 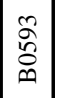 & 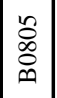 & $\stackrel{\delta}{\stackrel{\oplus}{\oplus}}$ & 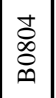 & $\begin{array}{l}n \\
\text { ò } \\
\infty\end{array}$ & 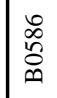 & 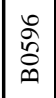 & $\mid \begin{array}{c}\tilde{\hat{~}} \\
\bar{y} \\
\infty\end{array}$ & $\begin{array}{l}\text { ఫิ } \\
\text { ఫิ }\end{array}$ \\
\hline $\begin{array}{l}\overrightarrow{0} \\
\text { ऐे } \\
\text { oे }\end{array}$ & ڤ્ّ & 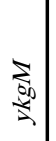 & 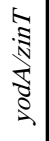 & $\mathbb{\Xi}$ & $\mid \begin{array}{l}\Xi \\
\text { I }\end{array}$ & ถิ & ปิ & $\$$ & 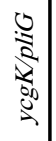 & 2 & § & 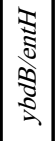 & ฐิ & $\Xi$ & 声 & $\stackrel{5}{2}$ & สิ & ปี & ป & : & $\overline{2}$ \\
\hline
\end{tabular}




\begin{tabular}{|c|c|c|c|c|c|c|c|c|c|c|c|c|c|c|c|c|c|c|c|c|}
\hline 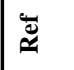 & $\overline{\widehat{\sigma}}$ & $\bar{\sigma}$ & $\overline{\vec{\sigma}}$ & $\widetilde{\widetilde{\sigma}}$ & $\bar{\Xi}$ & हु & $\bar{\Xi}$ & E & $\overline{\vec{v}}$ & $\overline{6}$ & $\sqrt{2}$ & 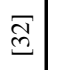 & 류: & $\widetilde{E}$ & 唐 & $\overline{6}$ & $\overline{\underline{b}}$ & వ్ర & 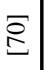 & $\Xi$ \\
\hline 产 & 煋 & 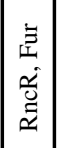 & ֶิ & 总 & 气े & 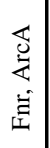 & 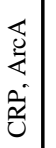 & O & 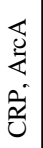 & 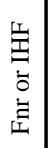 & $\begin{array}{l}\text { 志 } \\
\vdots \\
\vdots \\
\text { 至 }\end{array}$ & 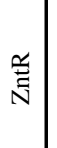 & 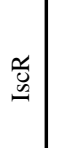 & 茞 & $\tilde{\tilde{z}}$ & 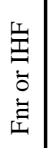 & 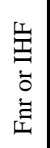 & $\begin{array}{l}0 \\
\text { 童 }\end{array}$ & 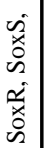 & 宝 \\
\hline 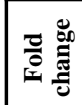 & $\stackrel{n}{1}$ & $\vec{i}$ & $\begin{array}{c}0 \\
0 \\
\infty \\
i\end{array}$ & $\stackrel{7}{T}$ & $\vec{T}$ & ?ִ & $\begin{array}{c}3 \\
\vdots \\
\vdots\end{array}$ & ְ̧ & $\vec{\varphi}$ & ip & $\vec{i}$ & ip & $\vec{r}$ & $\stackrel{\vec{f}}{\vec{f}}$ & $\stackrel{\infty}{\stackrel{\infty}{\rightarrow}}$ & f & $\stackrel{+}{+}$ & $\stackrel{m}{+}$ & $\stackrel{m}{+}$ & $\stackrel{\text { F }}{\mp}$ \\
\hline 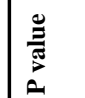 & 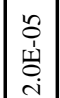 & 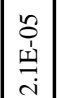 & 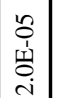 & 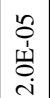 & o & $\begin{array}{l}n \\
0 \\
1 \\
1\end{array}$ & 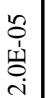 & $\begin{array}{l} \pm \\
0 \\
0 \\
0 \\
0\end{array}$ & $\begin{array}{l}n \\
\text { on } \\
\text { ch }\end{array}$ & క్ & 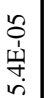 & 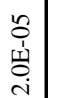 & $\begin{array}{l}0 \\
0 \\
0 \\
\dot{d} \\
i \\
i\end{array}$ & $\begin{array}{l}n \\
0 \\
\underline{d} \\
i \\
i\end{array}$ & 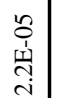 & \begin{tabular}{l}
0 \\
0 \\
$\vdots$ \\
\multirow{d}{0}{} \\
$i$
\end{tabular} & $\begin{array}{l}n \\
0 \\
\omega \\
\omega \\
n \\
n\end{array}$ & 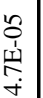 & 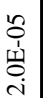 & $\begin{array}{l}\text { or } \\
\text { du } \\
\text { in }\end{array}$ \\
\hline
\end{tabular}

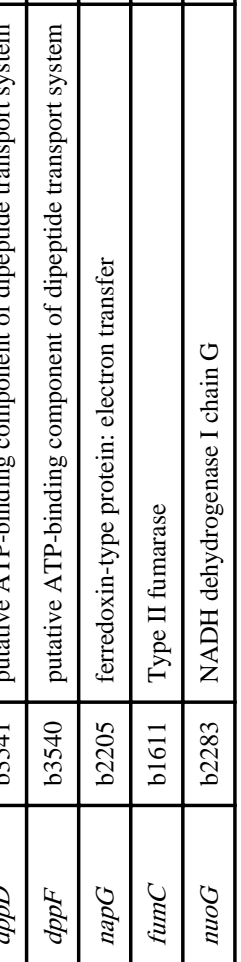


Table 3

Metal analyses of MBP-L31 and MBP-YkgM and mutants

\begin{tabular}{|l|c|}
\hline Protein & Zn(II) (equivalents) \\
\hline L31 as-purified & $0.3 \pm 0.1$ \\
\hline L31 metal-loaded & $1.2 \pm 0.1$ \\
\hline YkgM as-purified & $<0.01$ \\
\hline YkgM metal-loaded & $<0.01$ \\
\hline L31 (C16S) as-purified & $<0.01$ \\
\hline L31 (C16S) metal-loaded & $0.4 \pm 0.1$ \\
\hline L31 (C18S) as-purified & $0.03 \pm 0.01$ \\
\hline L31 (C18S) metal-loaded & $1.1 \pm 0.1$ \\
\hline L31 (C37S/C40S) as-purified & $0.4 \pm 0.1$ \\
\hline L31 (C37S/C40S) metal-loaded & $1.3 \pm 0.1$ \\
\hline
\end{tabular}


Table 4

Best fits to the Zn EXAFS of MBP-L31 and its C37S/C40S double mutant. ${ }^{a}$

\begin{tabular}{|l|c|c|c|}
\hline Sample & Zn-N/O & Zn-S & Zn-His $^{\boldsymbol{b}}$ \\
\hline MBP-L31 & $2.02(6.8)$ & $2.31(5.6)$ & $2.86(5.9), 3.09(1.0), 4.07(15), 4.44(16)$ \\
\hline MBP-L31 (C37S/C40S) & $2.01(5.2)$ & $2.29(5.3)$ & $2.88(9.8), 3.10(3.9), 4.12(15), 4.42(21)$ \\
\hline
\end{tabular}

${ }^{a}$ Distances ( $\AA$ ) and disorder parameters (in parentheses, $\sigma^{2}\left(10^{-3} \AA^{2}\right)$ ) shown derive from integer coordination number fits to filtered EXAFS data $\left[k=1-13 \AA^{-1} ; R=0.1-4.0 \AA\right]$.

${ }^{b}$ Multiple scattering paths represent combined paths, as described previously (see Experimental procedures). 